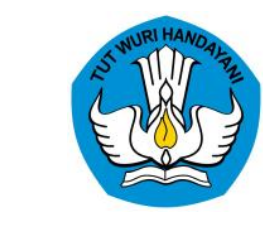

Check for updates

\title{
LOOKING For A TRACE OF SHAMANISM, IN THE ROCK ART OF MAROS-PANGKEP, SOUTH SULAWESI, INDONESIA
}

\author{
Irsyad Leihitu *, Raden Cecep Eka Permana \\ Departemen Arkeologi, Fakultas Ilmu Pengetahuan Budaya, Universitas Indonesia \\ Kampus FIB UI, Depok 16424, Indonesia \\ *irsyad.leihitu@gmail.com
}

Received: 26/02/2018; revisions: 10/03 - 03/06/2018; accepted: 13/06/2018 Published online: $31 / 07 / 2018$

\begin{abstract}
Rock art is an archaeological phenomenon which spread all over the world. Generally, this prehistoric art consists of various forms, motifs, and also meanings. This article discusses Indonesian rock art, particularly the Maros-Pangkep region in South Sulawesi. According to David Lewis-Williams and David S. Whitley's theory about the neuropsychology approach to rock art, they describe "some" motifs as a depiction of stages or metaphors of the Altered State of Consciousness (ASC) that relates to shamanism. The aim of this study is to demonstrate how the ASC theory can be tested in Maros-Pangkep Rock Art, and also shows an indication of the existence of shamanism in Indonesian rock art. The research methods are formal analogy and comparative studies on the selected motifs of rock art in the Maros-Pangkep region with African, Siberian, and also American rock art. The result shows that the ASC theory can be applied in Indonesian rock art and there are some indications of shamanism in rock art motifs in the Maros-Pangkep region.
\end{abstract}

Keywords: Rock art; Shamanism; Neuropsychology; Altered State of Consciousness; Trance; Maros-Pangkep, Formal Analogy

\section{INTRODUCTION}

Indonesian archaeologists today tend to agree on using "gambar cadas" as the most suitable term for rock art. Regardless of its type consisting of paintings or pictographs and carvings or petroglyphs, rock art commonly has various definitions. Rock art is defined as landscape art consisting of drawings, motifs and designs placed on natural and hard surfaces such as cliff walls, large boulders, cave walls and ceilings, and soil surfaces (Setiawan, 2015: 26; Whitley, 2005: 3). Rock art is an archaeological phenomenon that has spread almost all over the world, as its earliest examples are always associated with hunter-gatherer societies in prehistoric times (Pasaribu, 2016b: 1-2). In Indonesia, generally, rock art is widespread in some areas, especially in eastern Indonesia, namely South and Southeast Sulawesi, Maluku, West Papua, and more recently has also been found in Sumatra and Kalimantan (Permana, 2015: 4351; Wattimena, 2014: 47; Widianto et al., 2015: 92-391). Rock art in East Indonesian Prehistoric sites provides evidence of human migration (Jatmiko \& Mujabuddawat, 2016: 72), and based on the research so far, it is thought that the ancestors of South Sulawesi peoples came in gradually from the north and west (Wardaninggar, 2016: 121).

This research focuses on rock art in South Sulawesi, especially Maros and Pangkajene Kepulauan or Pangkep Regency. Rock art in the Maros-Pangkep Region was first discovered in the 1950s and has been recently studied intensively (Aubert et al., 2014: 1). This palaeolithic art typically consists of various shapes and motifs, including anthropomorphic ones, either human motifs or parts of human limbs, such as hand or foot marks, flora, fauna, line or geometric motifs, abstracts, mythological creatures such as half-animal, half-human or therianthrope, objects (weapons, common tools, and other artifacts), as well as various forms of certain symbols (Kosasih, 1983: 162). Among these motifs, the most common rock art motifs found in Maros-Pangkep is the hand-stencils (Permana et al., 2017: 711).

Since the first discovery of rock art in Spain by Don Marcelino de Sautuola in 1878 (Ucko \& Rosenfeld, 1967: 31-33), until the present experts sought to find out the functions and meanings of rock art. Basically, rock art is a person's expression of something they have seen 
(Salhuteru, 2009: 71), but sometimes it is too easy for archaeologists to interpret the meanings of rock art with general scientific labels (unilaterally, even without ever doing in-depth research). Archaeologists might even be described as aliens who feel able to simplify the meaning of cultural products that actually took thousands of years to achieve the formation of intact meaning (Ririmasse, 2007: 13). So far, many archaeologists have put forward theories and interpretations about the origin and meaning of rock art, such as secular art or art for art's sake, hunting magic, sympathetic magic, fertility magic, (Ucko \& Rosenfeld, 1983: 116-138), totemism, or Shamanism (Bahn \& Vertut, 1988: 149-165; Layton, 2000: 172; Lewis-Williams, 2004: 42-48; 175-176; Sauvet et al., 2009: 2). Among these theories, this article will focus on shamanism which is taken as currently the most advanced theory about rock art (Boivin, 2006: 1-2; Whitley, 2005: 109-110).

The study of shamanism theory in Indonesian rock art is certainly necessary, as such research will provide a new viewpoint within Indonesian rock art studies. However, until now it is very rare to find research that applies shamanism theory to Indonesia rock art. But that does not mean there is none, as Joshua Adrian Pasaribu in his thesis entitled Cultural Context of Animal Motif in Prehistoric Rock Art in South Sulawesi (2016) briefly discussed shamanism theory. Pasaribu (2016a: 10-15) stated that the cultural context of rock arts in South Sulawesi generally can be discovered based on the distribution and number or frequency of motifs. These cultural contexts include shamanism, totemism, and secular depictions. Based on the analysis of 25 sites including 84 animal motifs, and comparing them with Laura (Australia), Northen Cape (Africa), and Kimberley (Australia) sites, it can be determined that rock art in South Sulawesi is generally closer to the cultural context of totemism as compared to shamanism or secular depictions (Pasaribu, 2016a: 125-130).

In contrast to the research that Pasaribu has conducted, this study will use the method of formal analogy between motifs of rock art in Maros-Pangkep and the ASC model. This research will provide a new perspective in studying rock art in Indonesia, particularly in Maros-Pangkep region. Research with a similar approach was previously undertaken by Clottes \& Lewis-William who applied the method on paleolithic rock art in Europe (Berrocal, 2011: 9-10; Clottes \& Lewis-Williams, 2007).

\section{Theoretical Framework}

Shamanism theory in rock art refers to shamanic/magical activities originating from certain beliefs of the native community. This theory first appeared after the discovery of half animal-human motif on the Site of Les Trois-Frères Cave (Bahn \& Vertut, 1988: 158; Howell, 1965: 149; Layton, 2000: 177; Robbins, 1990: 50). It was later developed by David Lewis-William and David S. Whitley who combined ethnographic studies with neuropsychology (LewisWilliams, 2001: 332-360; 2004: 136-179). Shamanism rock art generally has certain characteristics drawn from its depiction of motifs that can be understood by comparison with nature or physical effect in trance, denoted by six metaphors of trance (Whitley, 2005: 109122; 2011: 308). Shamanism rock art is found in many sites around the world, including North America, Africa, some sites in Australia, and Siberia (Rozwadowski, 2014: 1). Interpretation of shamanism on rock art in these sites is generally based on ethnographic studies conducted on indigenous cultures and societies whose ancestral culture it is interpreted to present.

Shaman is a term derived from the Tungus, in central Siberia (Layton, 2000: 1), meaning "one who excited, moved, and raised" (Walsh, 1989: 2). Meanwhile, in African hunter-gatherer society, Kung San, similar people are known as medicine men (Woodhouse, 1989: 17). This term refers to someone who can heal, manipulate rain, and foretell the future (Putova, 2013: 4). In addition, a shaman is also believed to become a link between real world and supernatural world (LewisWilliams, 2004: 136-139). Meanwhile, Shamanism refers to a ritual performed by individuals or groups with the help of spirits of guardians or spirit (animal) helpers through trance or possession (Layton, 2000: 1; LewisWilliams, 2004: 139-141; Whitley, 2005: 110-115). Based on ethnographic studies, in general, a shaman has a spirit helper in the form of an animal. The animals that become spirit helpers during a state of trance are off different types in each region. In Africa for example, animal spirit helpers for the shaman include Eland (Lewis-Williams, 2004: 136-139), Bighorn in North America, especially on the Coso Range (Whitley, 2005: 118), and Elk on Yakutia, East Siberia (Rozwadowski, 2014: 1).

It was David Lewis-William who advanced the research of shamanism rock art by combining research with Informed (ethnographic) and formal (neuropsychological) approaches (Whitley, 2005: 109110). The complexity of applying these two approaches into a unified entity was addressed by conducting studies on rock art in the Drakensberg Mountains as well as rock art sites of San Society in South Africa (Sauvet et al., 2009: 3). Lewis-William believed that rock art in San Society is closely related to shamanic activity (he referred to these shamans as medicine men), especially trance activity in which a shaman explores the supernatural world (Lewis-Williams, 2004: 136-140). He used an approach or model called neuropsychological (N-P) to examine mental imagery for humans who 
experience an unconscious state such as possession or in this case known as Altered State of Consciousness.

$A S C$ is the main characteristic of shamanistic beliefs. Depictions made on the basis of experience or even in hallucinating conditions can lead to a conclusion that certain art originated from shamanistic-related ritual and belief. The N-P model sees a relationship between ASC phenomenon and the depictions in rock art, the purpose of study being to identify the origin of rock art itself. Thus, the N-P model is not used to find the meaning of rock art, but to understand the origin of its manufacture. The cross-cultural application of the N-P model is based on the fact that all humans both in the past and in modern life are neurologically equipped with the same 'program'. Therefore, our brains are all experience similar things in ASC (Whitley, 2005: 110-115). Shamans generally experience trance with or without the help of hallucinogenic plants such as mushrooms, tobacco, or jimson weed (Whitley, 2011: 312). However, trance state can also be experienced by fasting, staying in a quiet place, or dancing (Lewis-Williams, 2004: 140).

The similarity of brain reactions in the ASC or trance state does not mean that every trance that a person experiences will be the same as those of another individual, as each individual will experience different symptoms of trance that he/she has experienced. The difference is considered to be caused by their respective cultural upbringing. However, there are several potential reactions that occur in most people who undergo ASC. Lewis-William summarized the experience as having three stages;

- The first stage including the mildest symptoms for an individual going through a trance state is the experiencing of seven symptoms of entoptic patterns (a visual image that occurs or comes from within the visual). This is a naturally generated image from optical and neural systems for people who are going through ASC (sometimes also occurring in those who suffer from migraine and people who see a bright light experience it while closing their eyes). The seven patterns that usually appear are grids, dots, circles or stains, spirals and concentric, parallel lines and ticks, zigzags, meanders, and nested curves (Lewis-Williams, 2001: 337-339; Whitley, 1992: 111).

- The second stage is when the subject begins to construct a viewpoint that combines entoptic phenomena and iconic imagery or iconic images such as an animal or a herd of animals and/or certain objects (Lewis-Williams, 2001: 337-339; Whitley, 1992: 111)

- An intermediate stage is when the subject starts moving on the last stage. At this point, the subject usually goes through a journey through a tunnel or long hall with a bright light at the end. The tunnel is labeled as a vortex (Lewis-Williams, 2001: 337-339).

- The third stage is the peak stage of hallucinations, when the subject undergoes a strange or magical experience and goes through a changing situation. At this stage, it is also reported that the subject may feel changed into an animal. That transformation of body parts and/or somatic hallucinations are sensations of feeling something happening in the body but it is actually not real (Lewis-Williams, 2001: 337-339).

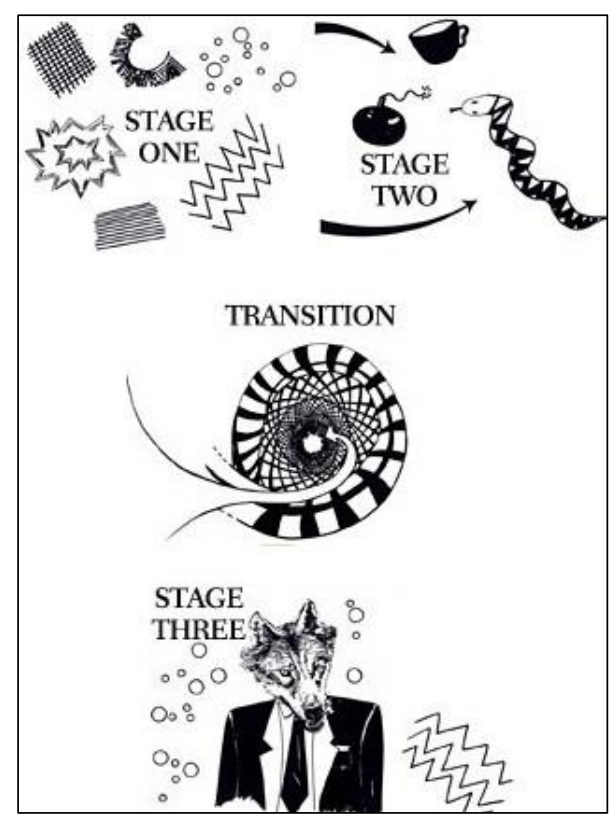

Figure 1. Three stages of $N$-P Model from Westerber (Source: Ornstein, 2017)

Based on these stages, Lewis-William (2004: 145146) depicted a cosmos system of a shaman's trance activity. He realized that there are three levels of nature types and the experienced phenomena when reaching certain levels. The first level is the upper world inhabited by certain spirits, then the second level is the real world which is a place to live in for humans or the world, and the third level is an underground world that is also inhabited by spirits. Only a shaman is able to relate to all levels of the world, by going through trance or ASC.

Table 1. Levels of cosmos N-P Model

\begin{tabular}{cc}
\hline Neuropsychology & Three Tiers \\
\hline Loss of body weight & Spirit world above \\
Parting with the body & (flight) \\
Attenuation &
\end{tabular}

\begin{tabular}{cc}
\hline Altered State of Consciousness & \multicolumn{1}{c}{ Daily Life } \\
\hline Vortex & $\begin{array}{l}\text { Spirit Realm Below } \\
\text { Underground and } \\
\text { Difficulty in breathing } \\
\text { Sounds in Ears }\end{array}$ \\
Underwater
\end{tabular}

Source: Lewis-Williams, 2004. "The Mind in The Cave". London: Thames \& Hudson 
The levels of cosmos postulated by Lewis-William then inspired Whitley in studying shamanism in North American rock art. Whitley confirmed interpretations of shamanistic rock arts by finding evidence of more specialized ASC phenomena. The study starts from concern with physical nature and hallucinations caused by trance, and how this physical effect can be manifested or embodied in the making of rock arts which he calls a metaphor of trance. Whitley believed that there are six physical metaphors commonly experienced in trance states:

- Death/killing or near-death experience or kill something

- Fighting/aggression or the experience of doing aggressive acts like fighting

- Magical flight or feeling like coming out of the body and floating

- Drowning/swimming or feeling like drowning or swimming in the water

- Sexual arousal/release or increased sexual arousal

- Bodily transformation or alteration of any part of the body (Whitley, 2005: 116)

In addition, Whitley in his rock art research in North America divided the type of shamanic activity into two, which is shamanic, considered as the individual activity of a shaman and shamanistic or activity carried out in groups by ordinary people or non-shamans (but still in the context of shamanism), usually performed in initiation ceremonies for grown boys or girls (LewisWilliams, 2004: 165-170; Whitley, 2011: 308-312).

Lewis-William and Whitley believed that these three stages and the above six metaphors are closely related to depictions of particular motifs in rock art. Both of them showed that the activity of ASC is recorded or depicted in rock art. An example would be the depiction of a halfeland/half-human in Africa which Lewis-William interpreted as a hallucinatory form of trance activity (Lewis-Williams, 2004: 140). Whitley in his North American study also conclude that the portrayal of a human with abnormal features represented a metaphorical description of a trance process (Whitley, 2005: 120)

Based on ethnographic studies that the two experts have conducted, it can be concluded that rock art is generally a tradition which is strongly related to religious or indigenous social beliefs, especially shamanism. Shamanism theory consisting of three stages of ASC and six types of metaphors in trance has been demonstrated on rock art on many sites in several parts of the world. In fact, David Lewis-William and his colleague Jean Clottes once examined ethnographic parallels between African rock art and upper paleolithic rock art in Europe, particularly concerning the site of Les Trois-Frères Cave. Based on this study, the results indicated that European rock art provided an indication that there was shamanism in the upper Paleolithic period (Clottes \& LewisWilliams, 1996: 84-96).

The difficulty of finding meaning in rock art motifs in Maros-Pangkep, South Sulawesi is due to a complete lack of ethnographic data on the site. However, our point of departure is Whitley's statement (2011: 321) that shamanism is likely to be the first beliefs of prehistoric human beings in the past scattered in several places in the world. Therefore, the issue of this research is "Is there any indication of shamanism on rock arts in MarosPangkep prehistoric cave sites?"

\section{Methods}

Archaeological research has systematic stages consisting of observation, description/analysis and explanation (Deetz, 1967: 8-11). Observation is the stage of collecting relevant literature and field data. Collection of literature is generally done by searching for books, articles, and journals related to research topics. Field data was obtained by survey conducted at Maros-Pangkep six prehistoric cave sites, There are 127 prehistoric cave sites in Maros-Pangkep, and 106 of them contains rock art in it (Mulyadi, 2016: 48). This research will focus on six prehistoric cave sites: Leang Ulu Tedong, Leang Ala Masigi, Leang Pamelakang Tedong, Leang Jin, Leang Kassi, Leang Kajuara.

The second stage is data description and analysis, in which the data collected in the previous stage are brought together and then the correlation between them is analyzed. Based on the results of the literature study, it can be concluded that there are some characteristics indicating rock art motifs as showing shamanism. These characteristics include: (1) There are geometric images which represent entoptic phenomena co-existing with the motif or around the motif (generally in the shaman's head or body), (2) There are tools or artifacts depicted, such as arrows, bows, and drums, (3) Disproportionate body shapes occur (e.g. having one of enlarged, elongated body part, etc.), and (4) There are motifs that are partanimal and part-human motifs.

The analysis conducted in this research uses a formal analogy method to match and look for similarity between shapes or attributes of rock art consonant with shamanism theory, especially the ASC stage of LewisWilliam and six kinds of metaphor from Whitley. In addition, this analysis compares rock arts in MarosPangkep with shamanism rock art in other regions such as America, Africa and Siberia. The third stage of research is data explanation by interpreting the object, which in this case is a rock art, on order to describe a behavior or aspect of human life in the past. 
This motif describes a creature that has the legs and posture of a human body but has a head that resembles an animal

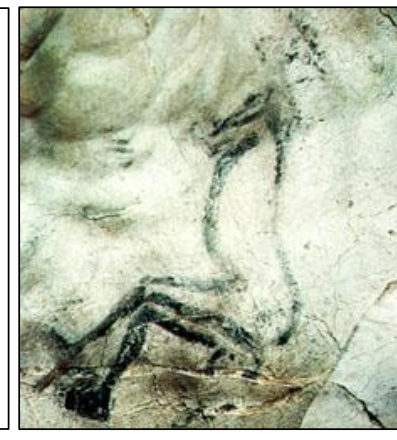

This depiction in the form of a half-animal creature is the third stage of $A S C$ and the sixth metaphor: bodily transformation

Figure 2. Shamanism theory of the Sorcerer motif in the Les Trois-Frères cave

(Source: The Editors of Encyclopaedia Britannica, 2015)

\section{RESULT AND DISCUSSION}

\section{Painting Description on Site}

As referred to above, the object of this research is rock art motifs in Leang Kajuara, Leang Kassi, Leang Ulu Tedong, Leang Alla Masigi, Leang Pamelakang Tedong in Pangkep and Leang Jin in Maros Regency.

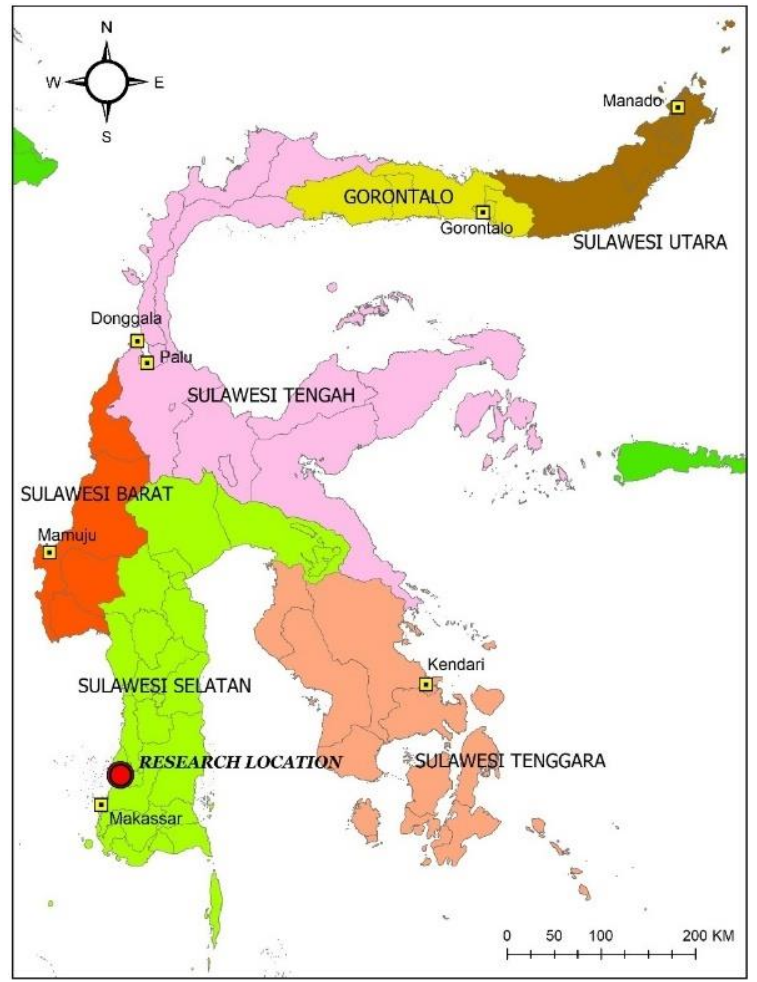

Figure 3. Research location marked by red dot (Source: Arsthen Peseletehaha, 2018)

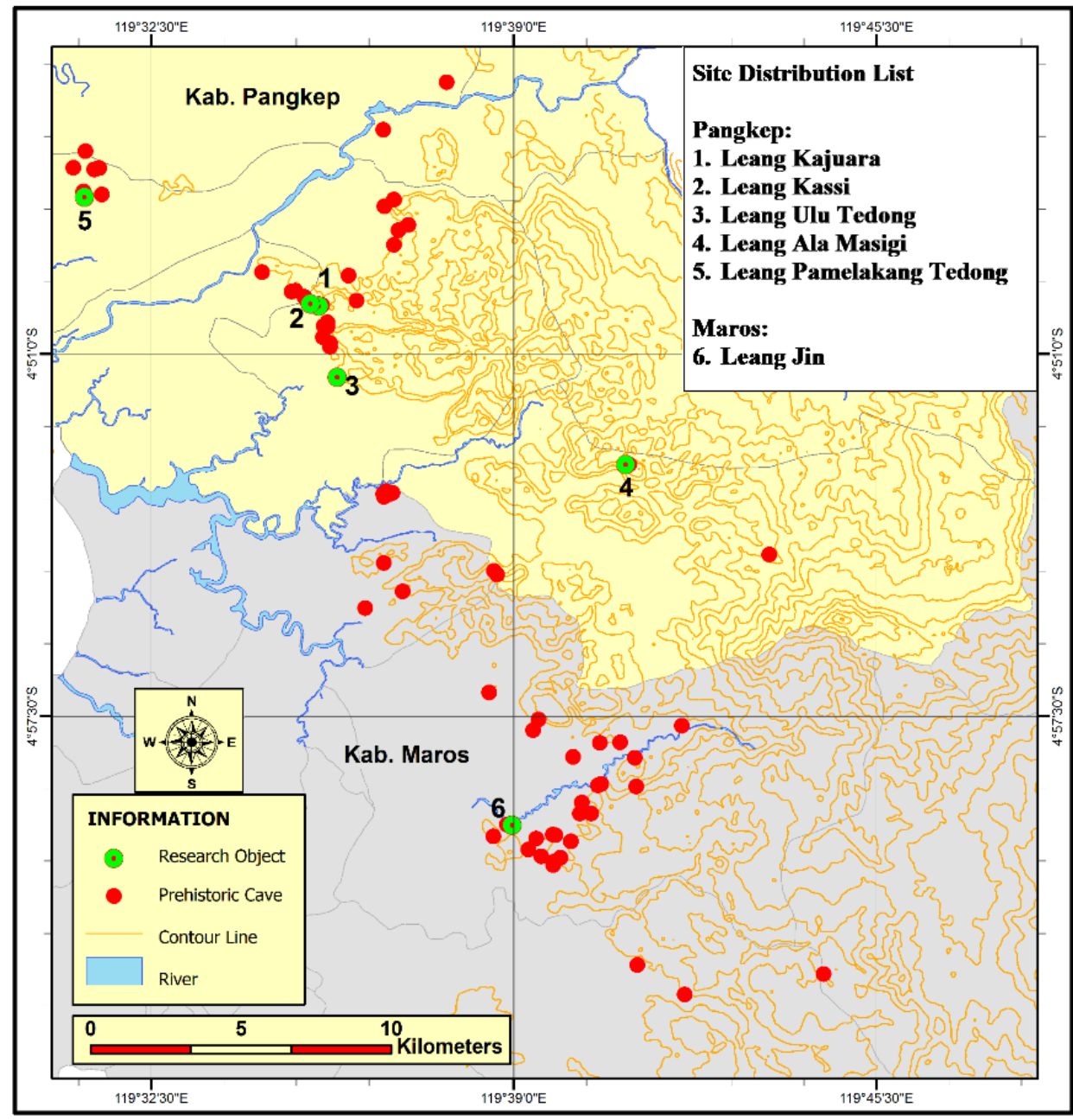

Figure 4. Distribution and Location of Sites (Source: Arsthen Peseletehaha, 2018) 


\section{Leang Kajuara}

This site is located in the administrative area of Kampung Belae, Biraeng Village, Minasate'ne District, Pangkep Regency. Leang Kajuara is in the area of Bulu Matojeng hills as well as Leang Caddia, Leang Lompoa, and Leang Kassi. Rock art in this cave is generally varied, but there is a unique figure that represents one of the characteristics of shamanism rock art.

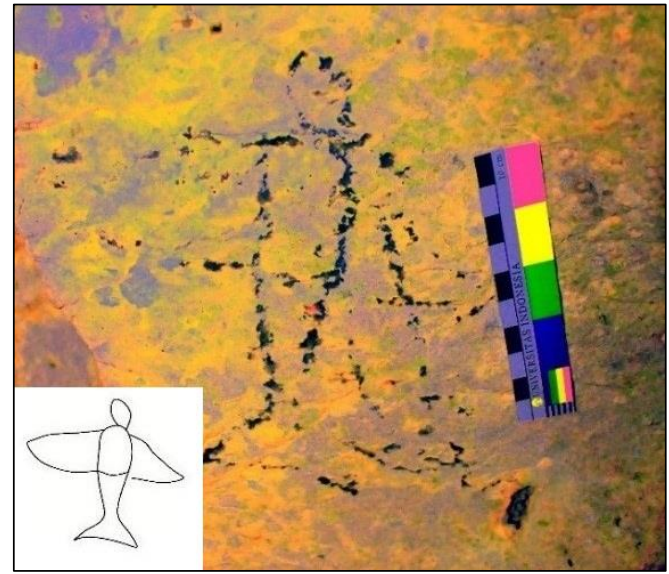

Figure 5. Theriantrope motif in Leang Kajuara with sketch (Source: Authors, 2017)

This figure was located on the cave ceiling and has an exceptional shape. This figure is depicted exactly in the middle of the panel in vertical position and has a black color in a nearly faded condition. Its distinctiveness lies in two pairs of wings on the left and right side with a tail similar to a bird, whereas its round head bears a resemblance to a human head.

\section{Leang Kassi}

The administrative location of this site is Kampung Belae, Biraeng Village, Minasate'ne District, Pangkep Regency. Access to this cave is by using four-wheeled or two-wheeled vehicles, but in order to get to the cave entrance, one needs to travel on foot by climbing the

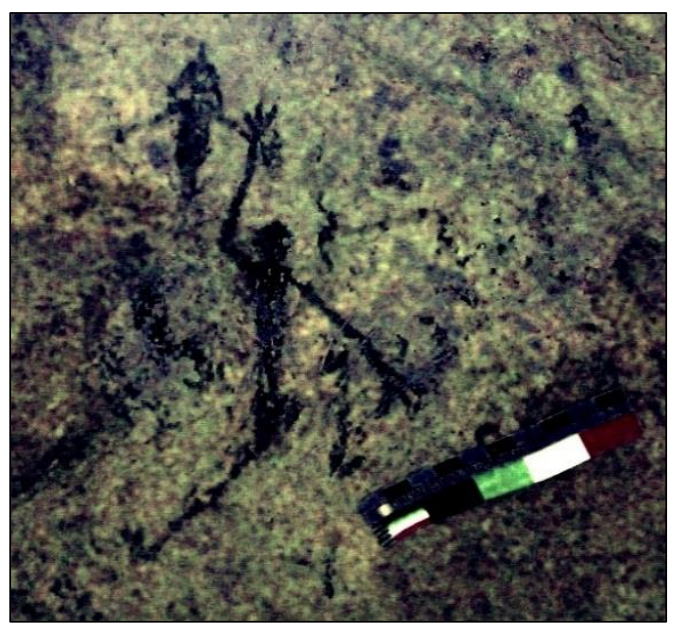

Figure 6. Human motifs in Leang Kassi after D'Stretch (Source: Authors, 2017) stairs. This cave contains several rock art paintings, but among them, there are two human figures with a unique shape.

These two human figures are depicted in black. The first figure (A) is the one of smaller size on the top left with outstretched hands (it looks like it is flying); the head is quite distinctive as there are three lines on the left, right, and top part. The second figure (B) is the larger one in the shape of a long body, hands, and legs; this figure looks like as if it trying to reach the first figure. By using the D'Stretch application, it turns out that there was another human motif on the left side but it was difficult to identify its shape.

\section{Leang Ulu Tedong}

It is located in Kampung Lamperangan, Kelurahan Kabba, Minasate'ne District, Pangkep Regency, South Sulawesi. The site is situated on a cliff with an altitude of about $100 \mathrm{~m}$ from the foot of the slope. Access to reach this site is by walking along the cliff on foot and then continuing by climbing a quite dangerous bamboo ladder which is slippery and somewhat delicate. Rock art contained in this site is varied, ranging from human figures and aquatic animals figures such as fish and turtle.

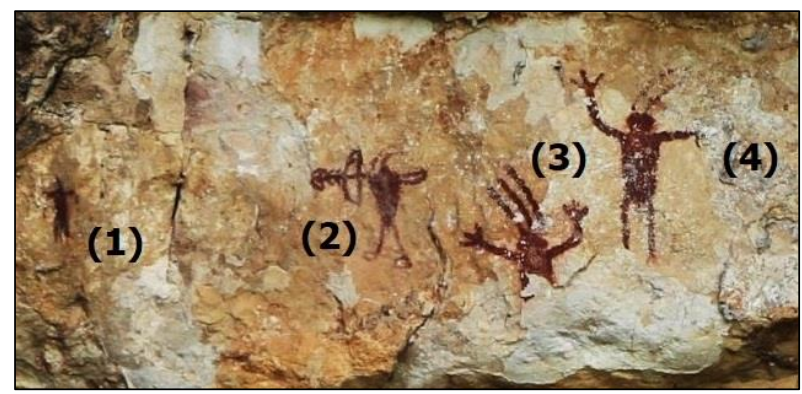

Figure 7. Panel 1 in Leang Ulu Tedong (Source: Authors, 2017)

In the first panel there are four human figures which look like they are illustrating a story scene. Figure 1 is located on the far left side of the panel and has the smallest size. This figure seems quite distinct compared to other motifs found on this site, as it is depicted with feet and hands in quite bold lines (no fingers), and has a sharp head. Figure 2 is located on the right side of figure 1 , this figure is depicted to be directing bow and arrows to figure 1. It also quite unique as it has a distinctive foot shape compared to other motifs, one that bears a resemblance to bird legs (with three digits), and there is also a vague representation of the phallus between the legs. At the head, this motifs has a long line perhaps depicting feathers. Human figure 3 is on the right side of figure 2. Figure 3 seems to have only the remaining half of the body as the bottom and legs have peeled off. Both hands of this figure are lifted up with three fingers and it has a head shape with three stripes on it. Human figure 4 


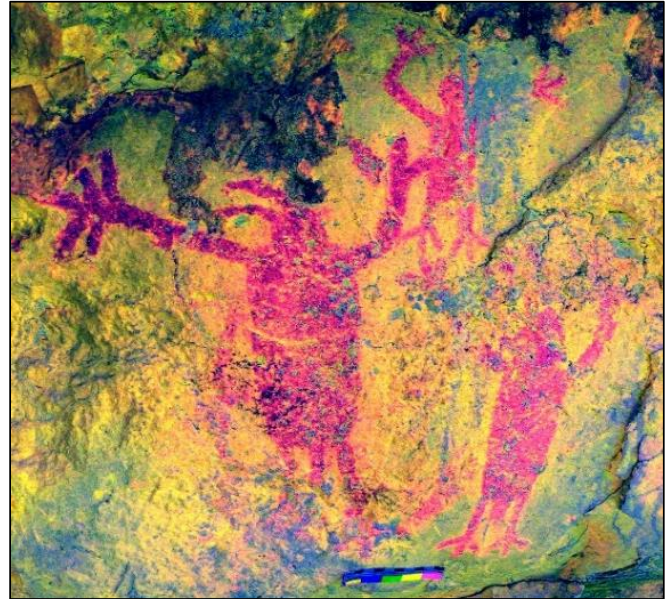

Figure 8. Panel 2 in Leang Ulu Tedong after D'Stretch (Source: Authors, 2017)

is on the far right side of the panel. The figure looks like it is facing figure 3. In addition. This last figure also has three fingers on both hands and there are two stripes on the head.

In the second panel there are three human figures. The first figure is the largest one, and it depicts an oval body shape and short legs with three toes. The hand part is also quite unique, as it has five fingers on the left side and only three fingers on the right. The head has three stripes. Human figure 2 is on the right of figure 1, its body also depicted in oval shape. Both hands and feet on this motif have three digits. The last motif, human figure 3 has the smallest size and is located in the middle between figure 1 and 2 . This pattern looks like it is waving towards human figures 1 and 2 with outstretched arms lifted up. Both hands and legs also possess three digits. Uniquely, these three motifs are depicted with a phallus between the legs.

\section{Leang Alla Masigi}

The cave is located in Bulu Balange Hill Kampung Batu Napara, Balocci District, Pangkep Regency. The Access to reach this cave can only be achieved on foot. In this cave, there are several rock art panel with animal and hand motifs. Among these motifs, there is one figure which is considered to be a shamanism rock art images. This "strange" figure is located at the bottom of the panel. The figure is depicted quite distinctively, as it is neither human nor animal, hence it is what is called a therianthrope. It has two legs with an almost round body shape, and the head is also unique as it does not have horns or eyes and nose, but only displays the mouth.

\section{Leang Pamelakang Tedong}

Administratively, this cave is located at Kampung Kayumate, Boringmasuggu Village, Labakkang District, Pangkep Regency. The cave is the part of the cluster in the Bulu Bukulu Hills, surrounded by rice fields, fish

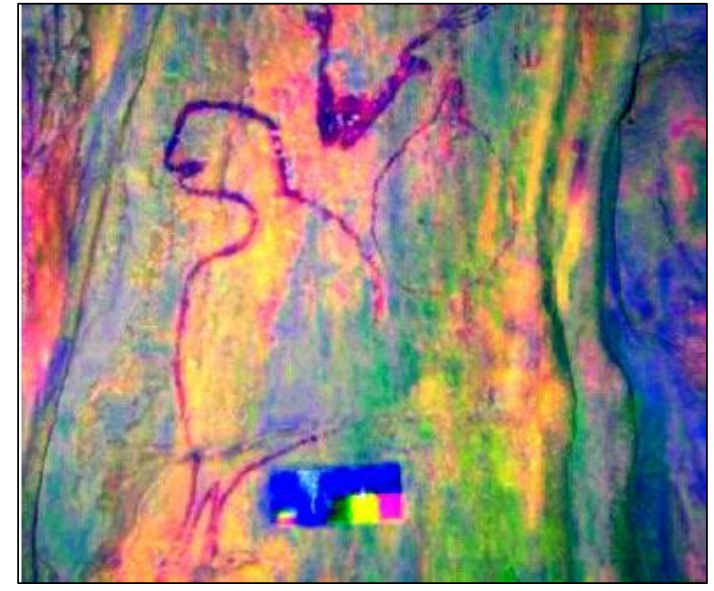

Figure 9. Theriantropee motif in Leang Alla Masigi after D'Stretch

(Source: BPCB Makassar in Pasaribu, 2016a)

ponds and gardens. Access to the cave is relatively easy, as it can be reached by walking through the rice field for a distance of about \pm 200 meters from the main road. On this site, there is one panel in which there are very small rock art motifs that look like they are depicting a ritual scene.

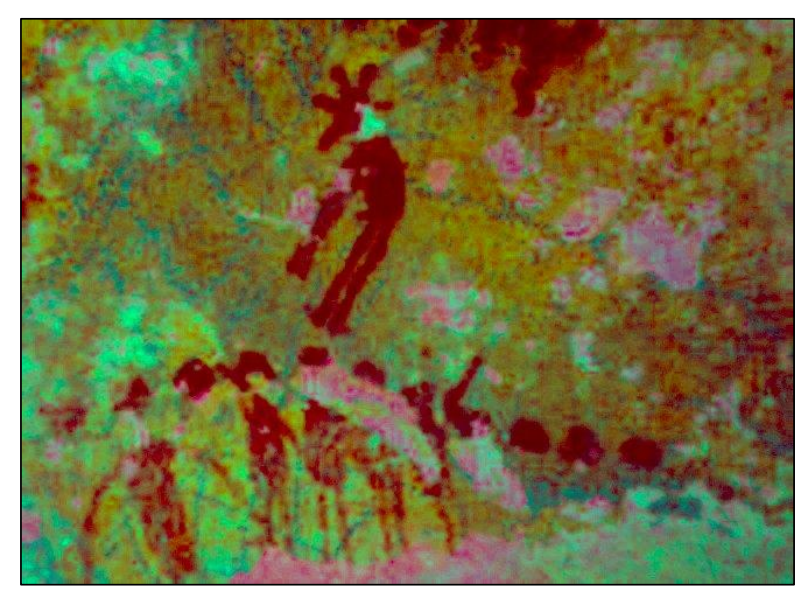

Figure 10. Human Motifs in Leang Pamelakang Tedong after D'Stretch

(Source: Authors, 2017)

The human figures that are found in this cave are quite exceptional, as it illustrates a complex ritual or ceremonial scene. In the bottom part there are about 11 human figures who are marching close together below a single human figure that looks like it is flying or floating. The human figure which is depicted as flying has a head portrayed with feather-like lines. In addition, there is a depiction of a phallus between the hands and feet.

\section{Leang Jin}

Leang Jin commonly called Jing is located in Kampung Lopi-Lopi, Kalbbirang Village, Bantimurung District, Maros Regency. In order to get to this cave, the access is quite easy due to the flat surface (Permana, 2014: 163). Leang Jin was the only cave found in Maros Regency in this study. In this cave there are several 


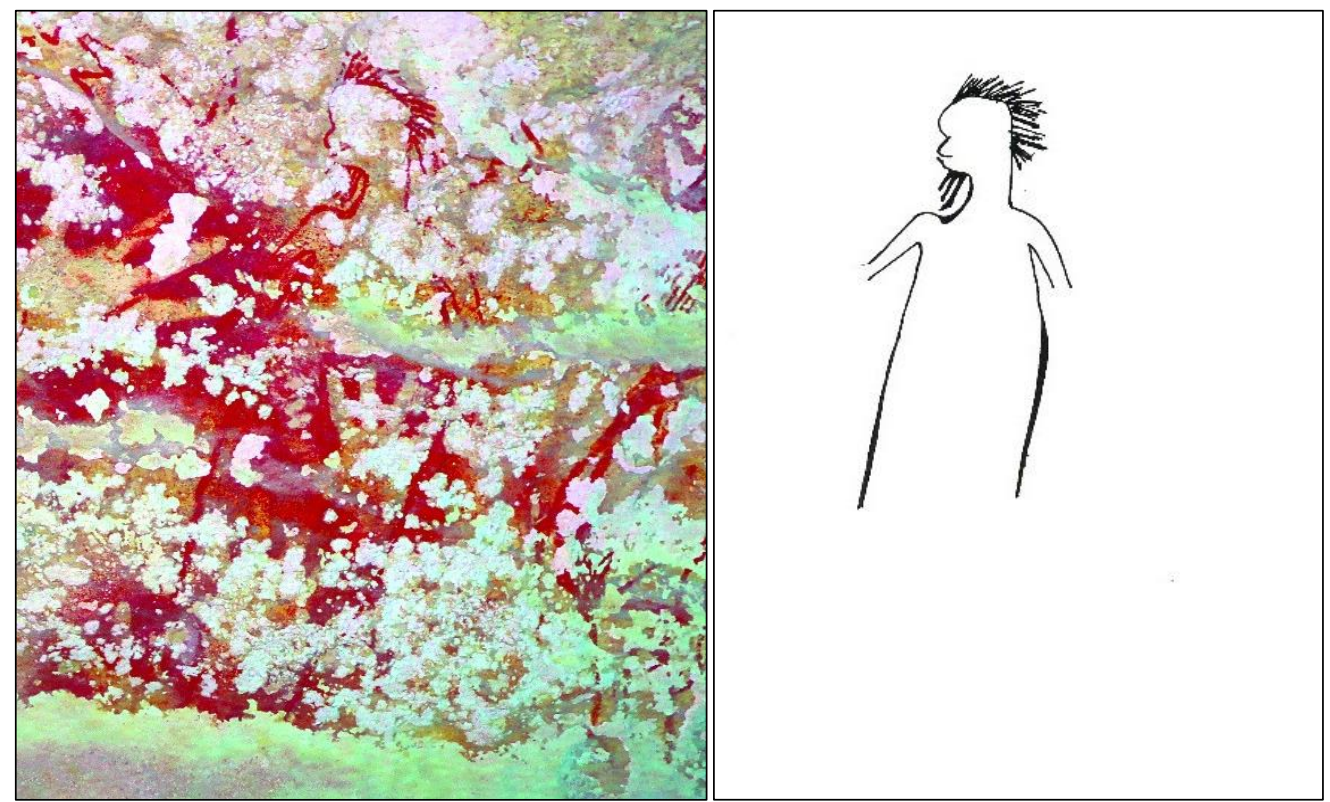

Figure 11. Human motif in Leang Jin after D'Stretch (Source: Authors, 2017)

motifs, among them are animal, humans, and hand stencils. This human figure - the only human figure in the cave - is very different from the previous ones. It is unique as its depiction is not a stickman, but in the form of almost natural shape. Using the D'Stretch application, it can be identified that this motif turns out to be longer than appears, but the end of the legs and hands have nearly vanished. In addition, this motif also has stripes resembling hairs on the head.

\section{Data Analysis}

As noted previously the data analysis in this research uses formal analogy or a process of identifying the rock art figures as described above to find similarities with those identified in shamanism theory, especially in the three stages of ASC by Lewis-William and the trance metaphor developed by Whitley. First, it is necessary to clarify, that every shamanism rock art depiction has some attributes that relate to trance metaphors and in some cases can represent more than one type of metaphor. In addition, this analysis also attempts to explain the activities of shamanism that are recorded in some of the rock art.

As discussed earlier, we believe that the therianthropic rock art in Leang Kajuara indicates shamanism. This is based on the assumption that the prehistoric society in Pangkep was experienced in proportionally drawing animal shapes. Accordingly, depictions of figure with such anomalous forms have other meanings and do not refer to ordinary animals.

This therianthrope figure is depicted with the body shape and wings of birds, while the head is depicted similar to a human head. According to Lewis-William (2001: 337339 ), the depiction of a mixed motifs between humans

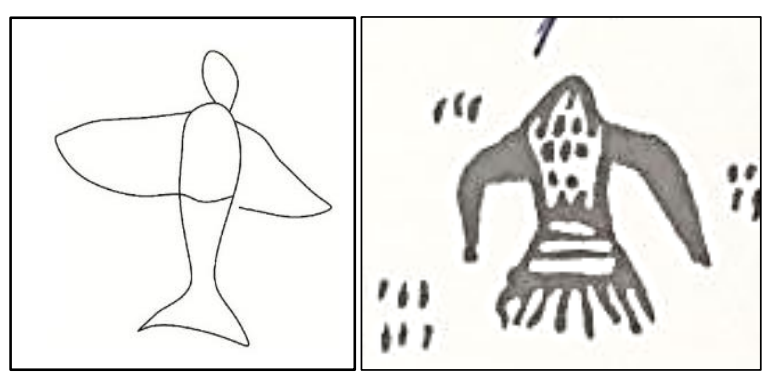

Figure 12. Bird man motif (left) and Flight Shaman motif in Tangaralakh, East Siberia (right)

(Source: Rozwadowski, 2014: 112)

and animals (in this case a bird) represents the ASC final stage, in which a shaman is in the peak of hallucinations and undergoes a change in his body, that is transformed in their mind into an animal.

Identification of the above therianthropic motif with ASC metaphorical theory proposed by Whitley shows that there are at least two types of metaphors depicted in this motif, bodily transformation and magical flight. Bodily transformation is one of the metaphors in which a shaman experiences a phenomenon of bodily distortion, while magical flight generally describes a scene in which the shaman undergoes the experience of flying like a bird. The figure of a "bird man" found in Leang Kajuara turns out to have similarity in terms of form and concept with the image of shamanism in the Site of Tangaralakh, East Siberia. Rozwadowski (2014: 112) suggested that this bird-shaped figure is a depiction of a shaman in Siberia transforming into a bird. He named this rock art motif as flight shaman.

In addition to the rock art in Leang Kajuara, the portrayal of the magical flight metaphor is also seen in rock arts in Leang Pamelakang Tedong. The depiction of human motifs in this cave is very important, since it may 
be the only one that clearly describes a shamanic ritual or activity recorded in the rock art corpus of the area. On this panel, there are eleven people standing close together, perhaps circling around a floating-like human figure. The figure of a flying person is thought to be the shaman. In addition to describing the metaphor of magical flight, the motif of the floating shaman is depicted with an erect or upright phallus represents a metaphor called sexual arousal. One of the symptoms that can be experienced by someone in a trance state is increased sexual arousal. In the case of men, it is generally characterized by an erection of genitals or phallus.

One of the unique things in this motif is depiction of lines on the head. The lines are very common in shamanic description, as they are believed to be animal hair commonly used as headscarves or energy emerging out of the shaman (Rozwadowski, 2014: 97-115). At sites like Coso Range in the North America and Yakutia in Siberia, the shamanic motifs are generally depicted in geometric lines on the head.

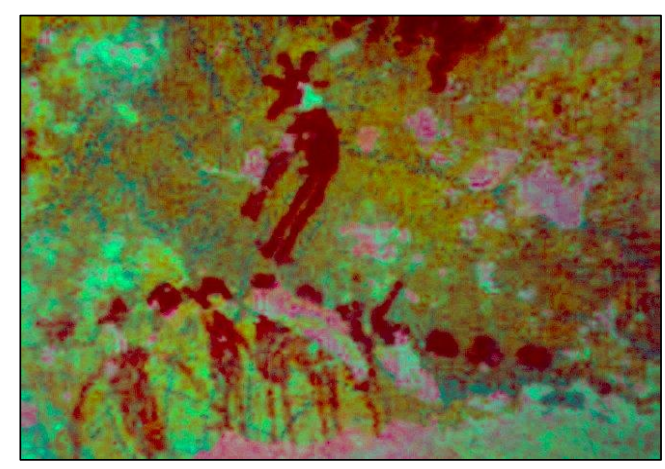

Figure 13. Scene of Magical Flight (Source: Authors, 2017)

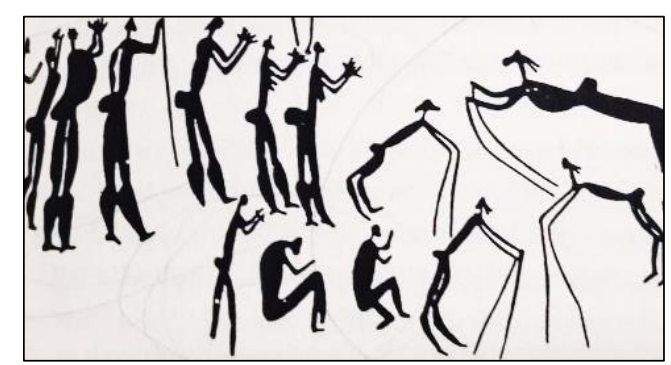

Figure 14. Rock art of Shamanism activity in the San Society site, South Africa

(Source: Lewis-Williams, 2004: 140)

The rock art in Leang Pamelakang Tedong illustrates shamanism activity. Depictions of activities generally associated with shamanism rituals are extremely uncommon. When compared to shamanism rock art at the San Society Site, South Africa, we can recognize the conceptual resemblance. There are human figures depicted standing close to each other and looking at the shaman (in the middle part who is depicted as halfanimal, half-humans) performing dances.
We argue that the most powerful features or attributes in the depiction of shamanism rock art are half-animal, half-human motifs or bodily transformation metaphors in the rock art found in Leang Kassi, Leang Alla Masigi, Leang Jin, and Leang Ulu Tedong. The reason why we are categorizing the human figures which are found in Leang Kassi as shamanism rock art is the indication of metaphorical bodily transformation. This is shown by the form of one of the human motifs as depicted disproportionately. The second human figure (in accordance with the previous description), is depicted with very long hands, feet and body, and only has three fingers. In addition, we also assume that the figure of the small creature with a unique head shape is a spirit/animal helper who accompanies the Shaman.

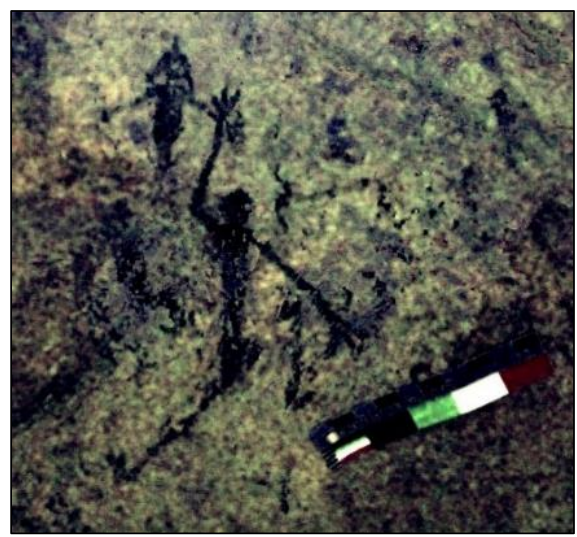

Figure 15. Disproportionate Body Shape (Source: Authors, 2017)

The figure in Leang Alla Masigi provides a clear indication of shamanism, This portrayal of a half-animal, half-humans represents the ASC final stage and the bodily transformation metaphor. The depiction of this figure is more like an animal than a human, which is quite similar to shamanism rock art in the San Society rock art site, in Africa. The depiction thereof an eland with an upright body position resembling a human being according to Lewis-William (2004) is a depiction of the ASC final stages that a shaman of the San Society experienced in the past.

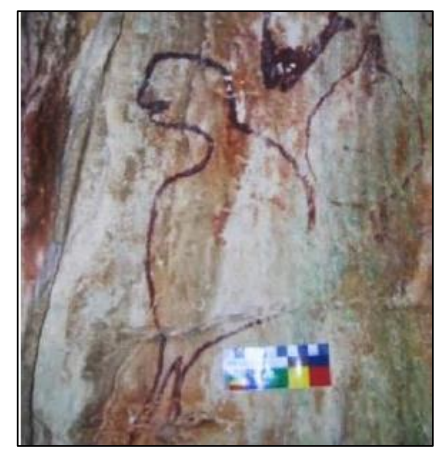

Figure 16. Bodily Transformation depiction in Leang Alla Masigi

(Source: BPCB Makassar in Pasaribu, 2016a) 


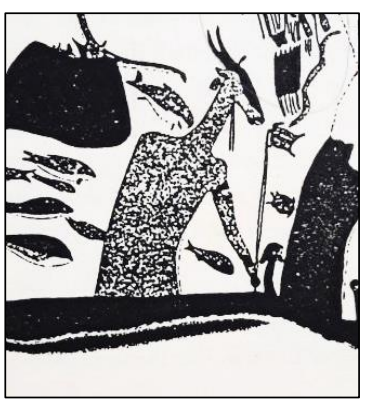

Figure 17. Rock art in San Society site, South Africa (Source: Lewis-Williams, 2004: 148)

The rock art at Leang Jin also represents the depiction of the bodily transformation metaphor. There are two things present as we also assume that the human figure in this cave is related to shamanism. The first is due to its unique depiction and difference from human figures in general and the depiction of hair-like lines on the head. In general, human figures in Maros-Pangkep rock art are always depicted facing forward or back to the observer (en-face), while animal figure are generally depicted with a side-on (en-profile) perspective. The depiction of humans with animal depiction techniques makes this figure distinctive.

The second feature is the elongated body shape. This is certainly related to the bodily transformation metaphor, and it also has a similarity to the American Barrier Canyon style (figure 19). Barrier Canyon style is well-
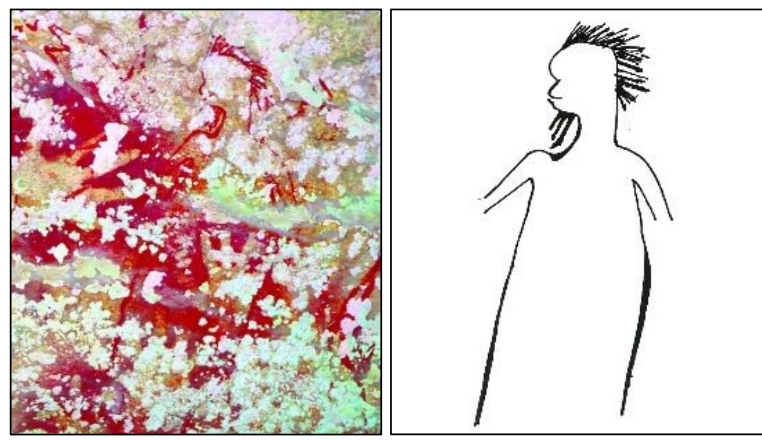

Figure 18. Human motif with elongated body in Leang Jin (Source: Authors, 2017)

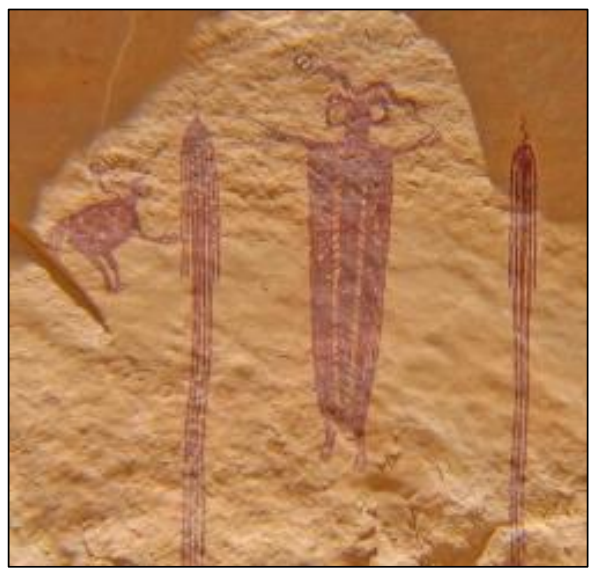

Figure 19. Shaman motifs with elongated body in Head of Sinbad site, United States (Source: Chabot, 2012) known from Head of Sinbad Site, in Utah, United States. American scholars generally associate this figures with a shaman. The shaman in this site is depicted with a long body and also has horns. The figure is depicted between two objects resembling very long furry creatures, The experts usually associate them with flywhisks or flyrepellent feathers which is one of the attributes of a shaman. Finally, no less important is depiction of spirit/animal helper on the left side of the rock art.

Before discussing the final rock art panels at Leang Ulu Tedong, we should add that in general there are various ways in which a shaman performs his duties when he seeks to communicate with the supernatural world. Some ways to perform are dancing, singing, clapping, as well as making certain kinds of music or sounds (Winkelman, 2002: 78-79; 2004: 195). In addition, a shaman is generally also equipped with some paraphernalia to use or wear in performing a ritual. These include fur robes (generally of leather or animal fur), headgear made of animal feathers (usually bird feathers), bows and arrows, drums (Rozwadowski, 2012; 197-198; 2014: 97-101), and also flywhisks or fly-repellent (Lewis-Williams, 2004: 147-148).

As described earlier, there are two panels in Leang Ulu Tedong which both have an indication of shamanism. In the first panel, the human figure 1 seems most hideous compared to the others. This figure has a long head vertically with both hands stretched out and the legs upright. Below its left and right hands there are some splotches (probably energy) and this figure also looks as if it is superimposed with a vague streak of black ink.

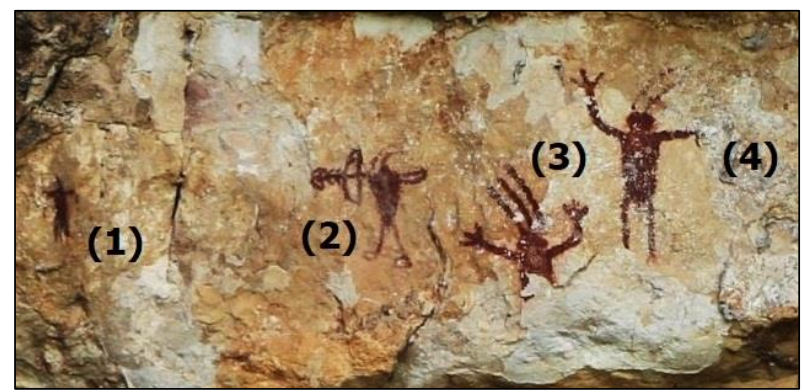

Figure 20. Shaman activity with paraphernalia in Panel 1 Leang Ulu Tedong

(Source: Authors, 2017)

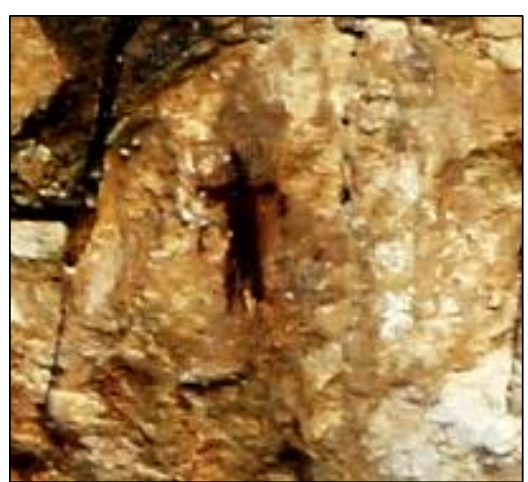

Figure 21. Human motif 1, hideous man (Source: Authors, 2017) 
Human figure 2 in this panel depicts a figure who is shooting an arrow, and it also seemingly has an antenna -like object on the head, perhaps representing a feather headdress. This motif represents two ASC metaphors of sexual arousal shown by the depiction of his phallus and Fighting/Aggression as he demonstrates archery activity. According to Rozwadowski (2014: 101) arrows have an important role in shamanic rituals in Eastern Siberia. Meanwhile, human figures 3 and 4 look like are facing each other (dancing?). Both of these figures have only three fingers on both hands with 'antennae' or feather headdresses on their heads. These figures reflect the third stage of ASC with two metaphors: Bodily Transformation and sexual arousal especially in figure 4 which depicts the phallus.

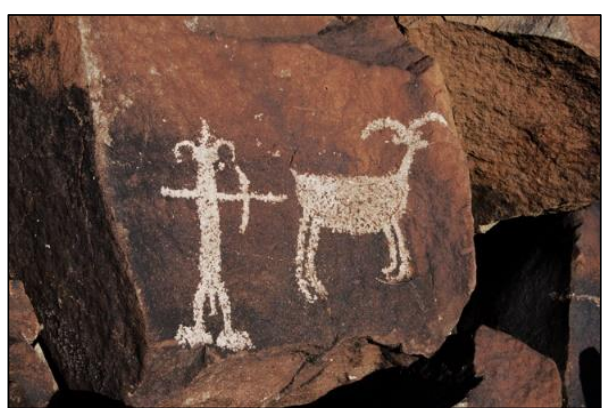

Figure 22. Rock art with Fighting/Aggression and sexual Arousal metaphors in the Coso Range site, United States (Source: Garfinkel, 2016)

In the second panel, all three figures have the same stripes resembling feathers or antennae on the head, and they also have three digits on both feet and hands. From the movements depicted, these motifs look like they are waving at each other or possibly dancing. They represent the third stage of ASC and describe two metaphors of bodily transformation and sexual arousal.

Based on the above explanation, it can be inferred that depictions of all figures above represent the third stage of ASC such as bodily transformation, sexual arousal, and fighting aggression. What is interesting about the rock art in this cave is that these figures are

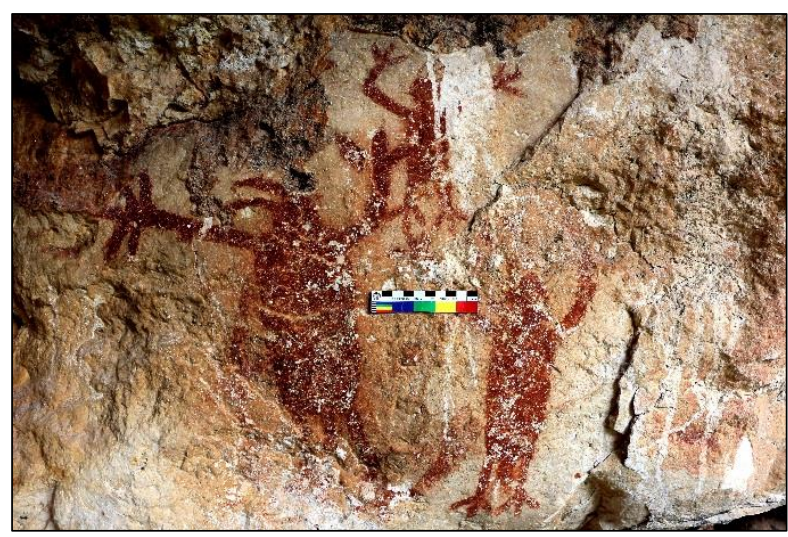

Figure 23. Scene of dance activity in Panel 2 Leang Ulu Tedong generally depicted with antennae or feathers (stripes on the head). It also important to note, concerning the scene in the first panel that Figure 2 is pointing an arrow towards the figure 1 on its left side. It is likely that this panel is depicting scene or story. Figure 1 is also quite distinctive, and we assume that this figure might be an evil spirit that the shaman must destroy. This perhaps rather wild assumption is based on David-Lewis William's account of shaman activity in the San Society of Africa, in which a shaman must fight with an evil spirit who is throwing arrows and inflicts illness (LewisWilliams, 2004: 136-140).

\section{Conclusion}

Analysis of the above figures clearly shows that there is an indication of the culture or tradition of shamanism in Indonesia. This conclusion was derived from the formal analogy method which compared the rock arts on Leang Kajuara, Leang Kassi, Leang Ala Masigi, Leang Ulu Tedong, Leang Pamelakang Tedong, and Leang Jin with theories of shamanism rock arts. There are several metaphors of ASC (particularly bodily transformation, sexual arousal, fighting/aggression, and magical flight) and also some ritual and attributes of shamanistic beliefs which is recorded or depicted in rock art on those sites. In addition, the above figures also present a similarity of features and shapes to the shamanism rock arts found on sites in America, Africa, and Siberia. The sample of images of rocks in the sites above are definitely just a small part of the sites in Maros-Pangkep Regency. This study also shows that the theory of shamanism and neuropsychology from David Lewis-William and David S. Whitley can be applied to the rock art of Indonesia. However, it should be emphasized once again that this study only represents an indication. Whether or not these rock art panels are a result of shamanic practice is very difficult to prove, because of the lack of relevant ethnographic data in the district of Maros-Pangkep. Certainly, it requires more in-depth study to understand the tradition of shamanism in both districts.

\section{ACKNOWLEDGEMENT}

Our gratitude goes to Karina Arifin, Ph.D. who has opened the knowledge and interest to pursue Shamanism in the research of rock art. We also thank Joshua Pasaribu, M.Hum. who has represented the therianthrope motif in Leang Alla Masigi, BPCB and Balar Makassar which have helped the process of data collection, and Arsthen Peseletehaha, S.S. who provided maps of site location.

(Source: Authors, 2017) 


\section{REFERENCES}

Aubert, M., Brumm, A., Ramli, M., Sutikna, T., Saptomo, E. W., Hakim, B., Morwood, M. J., van den Bergh, G. D., Kinsley, L., \& Dosseto, A. (2014). Pleistocene cave art from Sulawesi, Indonesia. Nature, 514(7521), 223.

Boivin, N. (2006). Shamanism and Indian Rock Art. Before Farming, 4(2), 1-3.

Bahn, P. G., \& Vertut, J. (2016). Images of the ice age. Oxford University Press.

Berrocal, M. C. (2011). Analogical evidence and shamanism in archaeological interpretation: South African and European Palaeolithic rock art. Norwegian Archaeological Review, 44(1), 1-20.

Chabot, R. (2012). Rock Art Site - Head of Sinbad Pictographs. Retrieved January 17, 2018, from https://ancient-graffiti.com/

Clottes, J., \& Lewis-Williamss, D. (1996). Upper palaeolithic cave art: French and South African collaboration. Cambridge Archaeological Journal, 6(1), 137-139.

Clottes, J., \& Lewis-Williamss, D. (2007). Les chamanes de la préhistoire: transe et magie dans les grottes ornées: suivi de Après les chamanes, polémique et réponses, 379. Seuil.

Deetz, J. (1967). Invitation to Archaeology. New York: Natural History Press.

Garfinkel, A. P. (2016). The Rock Art Engravings of The Coso Range. Retrieved January 20, 2018, from http://www.bradshawfoundation.com/

Howell, C. F. (1965). Early Man. New York: Time Life Books.

Jatmiko, n., \& Mujabuddawat, M. (2016). Jejak Budaya Paleolitik di Pulau Seram: Kajian Migrasi Manusia Awal di Wilayah Indonesia Timur. Kapata Arkeologi, 12(1), 71-78.

Kosasih, E. A. (1983). Lukisan Gua di Indonesia sebagai Sumber Data Penelitian Arkeologi. In Pertemuan Ilmiah Arkeologi III (pp. 158-172). Jakarta: Pusat Arkeologi Nasional.

Layton, R. (2000). Shamanism, Totemism, and Rock Art: Les Chamanes de la Prehistoire in the Context of Rock Art Research. Cambridge Archaeological Journal, 10(1), 169-186.

Lewis-Williams, D. (2001). Brainstorming Images: Neuropsychology and Rock Art Research. In D. S. Whitley (Ed.), Handbook of Rock Art Research (pp. 332357). California: AltaMira Press.

Lewis-Williams, D. (2004). The Mind in the Cave: Consciousness and the Origins of Art. London: Thamess \& Hudson.

Mulyadi, Y. (2016). Distribusi dan Sebaran Situs Gambar Cadas di Indonesia: Sintesis Penelitian. Jurnal Arkeologi Malaysia, 29(2), 43-56.

Permana, R. C. E. (2014). Gambar Tangan Gua-Gua Prasejarah Pangkep-Maros Sulawesi Selatan. Jakarta: Wedatama Widya Sastra.

Permana, R. C. E. (2015). Lukisan Dinding Gua (Rock Art) Keterancaman dan Upaya Konservasinya. Jurnal Konservasi Cagar Budaya Borobudur, 9(2), 43-51.

Permana, R. C. E., Pojoh, I. H. E., Arifin, K. (2017). Mabedda Bola ritual in South Sulawesi: The Relationship between handprints in traditional houses and hand stencils in prehistoric caves. Wacana, 18(3), 692-717.

Pasaribu, Y. A. (2016a). Konteks Budaya Motif Binatang Pada Seni Prasejarah di Sulawesi Selatan. Depok: Thesis Universitas Indonesia.

Pasaribu, Y. A. (2016b). Konteks Budaya Motif Binatang Pada Seni Prasejarah di Sulawesi Selatan. Paradigma Jurnal Kajian Budaya, 6(1), 1-27.

Putova, B. (2013). Prehistoric Sorcerers and Postmodern Furries: Anthropological Point of View. International Journal of Sociology and Anthropology, 5(7), 243-248.
Ririmasse, M. (2007). Tinjuan Kembali Seni Cadas di Maluku. Kapata Arkeologi, 3(4), 1-21.

Robbins, L. H. (1990). The Archaeologist's Eye. London: Robert Hale London.

Ornstein, R. (2017). Ideas That Shaped Our Modern World. Retrieved January 15, 2018, from http://www.humanjourney.us/

Rozwadowski, A. (2012). Rock Art, Shamanism and History: Implications From a Central Asian Case Study. In B. Smith, D. Morris, K. Helskog, N. Agnew, C. Chippindale, J. Deacon (Ed.), Working with Rock Art: Recovering, Presenting and Understanding Rock Art Using Indigenous Knowledge (pp. 192-20). Johannesburg: Wits University Press.

Rozwadowski, A. (2014). In Search of Shamanic Themes in Eastern Siberian Rock Art (Sakha/Yakutia Republic). Shaman, 22(1-2), 97-118.

Salhuteru, M. (2009). Situs Lukisan Cadas di Desa Wamkana Kabupaten Buru Selatan. Kapata Arkeologi, 5(8), 69-77.

Sauvet, G., Layton, R., Lenssen-Erz, T., Taçon, P., Wlodarczyk, A. (2009). Thinking with Animals in Upper Palaeolithic Rock Art. Cambridge Archaeological Journal, 19(3), 118.

Setiawan, P. (2015). Pendahuluan. In R. C. E. Permana (Ed.), Gambar Cadas Prasejarah di Indonesia (pp. 1-30). Jakarta: Direktorat Pelestarian Cagar Budaya dan Permuseuman, Kementerian Pendidikan dan Kebudayaan.

The Editors of Encyclopaedia Britannica. (2015). Trois Frères, cave in Ariège, France, containing an important group of Late Paleolithic paintings and engravings. Retrieved January 5, 2018, from http://www.britannica.com/

Ucko, P. J. \& Rosenfeld, A. (1967). Palaeolithic Cave Art. London: World University Library.

Walsh, R. (1989). What is a Shaman? Definition, Origin and Distribution. The Journal of Transpersonal Psychology, 21(1), 1-10.

Wardaninggar, B. (2016). Sebaran Potensi Budaya Prasejarah di Enrekang, Sulawesi Selatan. Kapata Arkeologi, 12(2), 113-124.

Wattimena, L. (2014). Lukisan Cadas: Simbolis Orang Maluku. Kapata Arkeologi, 10(1), 47-54.

Whitley, D. S. (1992). Shamanism and rock art in far western North America. Cambridge Archaeological Journal, 2(1), 89-113.

Whitley, D. S. (2005). Introduction to Rock Art Research. California: Left Coast Press inc.

Whitley, D. S. (2011). Rock art, Religion, and Ritual. In T. Insoll (Ed.), Oxford Handbook of The Archaeology of Ritual and Religion (pp. 307-326). Oxford: Oxford University Press.

Widianto, H., Arifin, K., Permana, R. C. E., Setiawan, P., Said, A. M., Oktaviana, A. A. (2015). Gambar Cadas Prasejarah di Indonesia. Jakarta: Direktorat Pelestarian Cagar Budaya dan Permuseuman, Kementrian Pendidikan dan Kebudayaan.

Winkelman, M. (2002). Shamanism and Cognitive Evolution. Cambridge Archaeological Journal, 12(1), 71-101.

Winkelman, M. (2004). Shamanism as The Original Neurotheology. Zygon® Journal of Religion \& Science, 39(1), 193-217.

Woodhouse, H. C. (1989). Motivation and The Rain Animal In The Rock Art of Southern Africa. Suid-Afrikaanse Tydskrif vir Kunsgeskiedenis, 4(2\&3), 15-25. 